\title{
Isolation of a novel paxilline analog pyrapaxilline from fungus that inhibits LPS-induced NO production
}

\author{
Chino Matsui ${ }^{1}$, Yoko Ikeda ${ }^{1}$, Hironobu Iinuma ${ }^{2}$, Nobuaki Kushida ${ }^{3}$, Takao Kunisada ${ }^{3}$, Siro Simizu ${ }^{1}$ \\ and Kazuo Umezawa ${ }^{4}$
}

We have screened microbial culture filtrates for nitrogen monoxide (NO) production inhibitors using mouse macrophage cell line RAW264.7. As a result, paxilline, 21-isopentenylpaxilline and a novel analog of paxilline have been isolated from the culture filtrate of fungus Eupenicillium shearii. The novel analog possesses an additional dihydropyran ring, and was named as pyrapaxilline. This compound inhibited the NO production with lower toxicity than paxilline.

The Journal of Antibiotics (2014) 67, 787-790; doi:10.1038/ja.2014.63; published online 4 June 2014

\section{INTRODUCTION}

Nitrogen monoxide (NO) produced by endothelial nitric oxide synthase often has an important role regulating many physiological functions such as vasodilation and neurotransmission. However, overproduction of NO by inducible NO synthase mainly in macrophages often accelerates inflammatory diseases including atherosclerosis, rheumatoid arthritis, septic shock, multiple sclerosis, diabetes mellitus and graft rejection. ${ }^{1}$ Therefore, suppression of NO production or inducible NO synthase expression might be important for the treatment of inflammatory disorders. Lipopolysaccharide (LPS) induces inducible NO synthase expression that is mainly mediated by transcription factor NF- $\mathrm{KB}$ (nuclear factor- $\mathrm{\kappa B}$ ). Therefore, screening of LPS-induced NO production inhibitors may provide new NF- $\mathrm{KB}$ inhibitors. We previously designed a novel NF- $\mathrm{\kappa B}$ inhibitor dehydroxymethylepoxyqinomicin from the structure of antibiotic epoxyquinomicin C., ${ }^{2,3}$ It showed potent anti-inflammatory and anticancer activities in animals. ${ }^{4}$ We also isolated a known glutarimide compound, 9-methylstreptimidone ${ }^{5}$ from the culture filtrate of Streptomyces and known penicillic acid and dihydropenicillic acid ${ }^{6}$

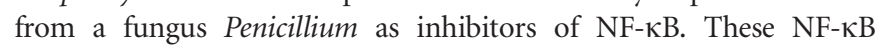
inhibitors except dehydroxymethylepoxyqinomicin were isolated first as NO production inhibitors. Therefore, screening of LPS-induced NO production inhibitors may provide further effective antiinflammatory agents. Then, we looked for the novel inhibitors among microbial secondary metabolites. As a result, we found a novel paxilline analog named pyrapaxilline from the static culture filtrate of fungus Eupenicillium shearii.

\section{RESULTS}

The producing strain and isolation

We have prepared and screened about 1000 microbial filtrates for NO production inhibitors. Microbial culture filtrate from a fungus
PF1443 (CR25679) showed potent inhibitory activity on LPS-induced NO production. The producing organism was identified to be E. shearii as described in Methods. For the purification of active principle, static culture of this fungus was extracted with $67 \%$ aq acetone and then EtOAc to give a dried brown residue. The residue was subjected to column chromatography on silica gel 60 . After the concentration of active fractions, the yellow residue was obtained. The $\mathrm{MeOH}$ solution of this residue was further purified on HPLC column to give three compounds (1-3). Compounds $\mathbf{1}$ and $\mathbf{2}$ were identified as paxilline ${ }^{7}$ and 21 -isopentenylpaxilline, ${ }^{8}$ respectively, from their spectral data. The spectral data of compound 3 had never been reported, and was shown to be a novel analog of 1 (Figure 1).

\section{Structure elucidation}

The molecular formula of 3 was determined as $\mathrm{C}_{37} \mathrm{H}_{47} \mathrm{NO}_{5}$ by HRESIMS. The 2D NMR analysis in $\mathrm{CD}_{3} \mathrm{OD}$ (Table 1 ) and NOESY experiment in $\left(\mathrm{CD}_{3}\right)_{2} \mathrm{SO}$ (Figure 2) exhibited to be an indolediterpene having an additional substituted dihydropyran ring linked with the indole unit of $\mathbf{1}$. The paxilline moiety at C-21 and C-22 (that is, C-29 in 3), fused with five-membered ring of the indene portion, biogenetically derived from two isopentenyl side chains ${ }^{9}$ (Figure 1). The numbering of 3 is shown according to that of janthitrems ${ }^{10}$ and shearinines. ${ }^{8,11}$ The ${ }^{1} \mathrm{H}$ and ${ }^{13} \mathrm{C}$ NMR spectra of $\mathbf{3}$ were measured in $\mathrm{CD}_{3} \mathrm{OD}$ rather than in $\mathrm{CDCl}_{3}$, because the structural change occurred in the latter solvent. ${ }^{10}$ The linkage of the dihydropyran and fivemembered rings at $\mathrm{C}-23$ and $\mathrm{C}-28$ was established by NOESY experiment in $\left(\mathrm{CD}_{3}\right)_{2} \mathrm{SO}$. The NOE correlations of $30-\mathrm{H}(\delta$ 7.01) to $27-\mathrm{H}(\delta \quad 2.33)$ and to $1-\mathrm{NH}(\delta$ 10.56) were observed (Figure 2$)$. Among the known paxilline-related compounds, shearinine $B^{8}(4)$ has the same molecular formula with 3 . But, the structure of $\mathbf{3}$ at $\mathrm{C}-23$ and $\mathrm{C}-27$ was different from those of 4 . In ${ }^{1} \mathrm{H}$ NMR data of 3

\footnotetext{
${ }^{1}$ Department of Applied Chemistry, Faculty of Science and Technology, Keio University, Yokohama, Japan; ${ }^{2}$ Bioscience Associates, Tokyo, Japan; ${ }^{3}$ Meiji Seika Pharma Co. Ltd, Tokyo, Japan and ${ }^{4}$ Department of Molecular Target Medicine Screening, Aichi Medical University School of Medicine, Nagakute, Japan

Correspondence: Professor K Umezawa, Department of Molecular Target Medicine Screening, Aichi Medical University School of Medicine, 1-1 Karimata, Yasago, Nagakute, Aichi 480-1195, Japan.

E-mail: umezawa@aichi-med-u.ac.jp

Received 14 November 2013; revised 30 March 2014; accepted 4 April 2014; published online 4 June 2014
} 


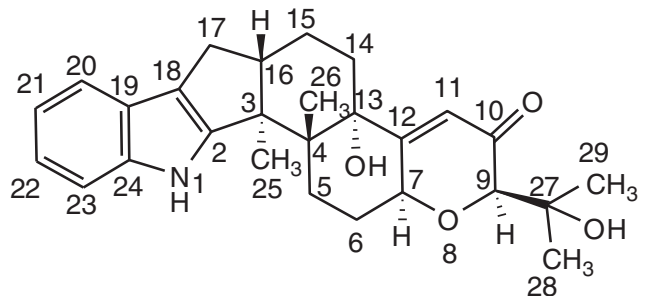

paxilline (1)<smiles>CC(C)=CCc1ccc2[nH]c3c(c2c1)C[C@H]1CC[C@]2(O)C4=CC(=O)[C@@H](C(C)(C)O)OC4CC[C@@]2(C)[C@]31C</smiles>

21-isopentenylpaxilline (2)
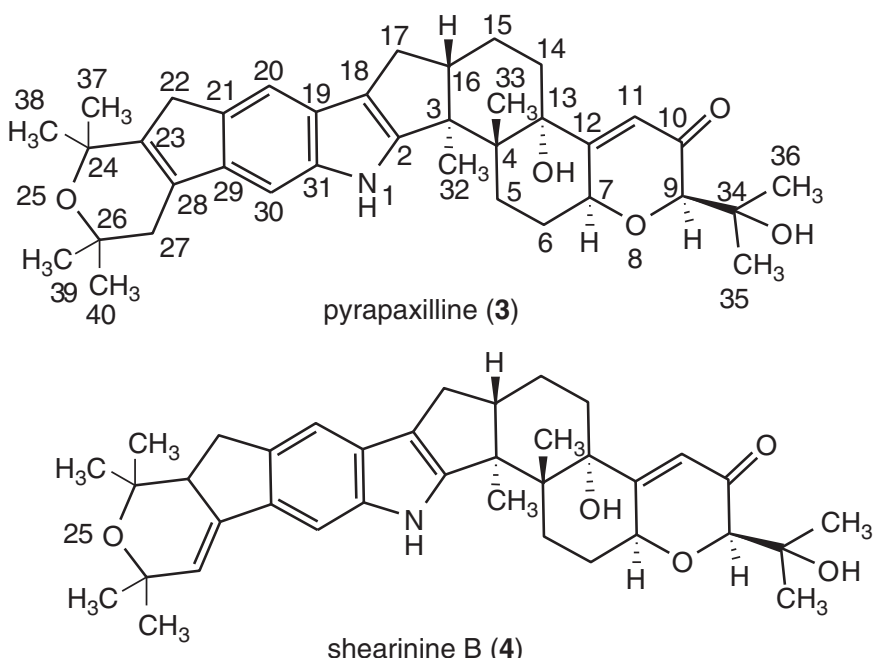

shearinine B (4)

Figure 1 Structures of paxilline, 21-isopentenylpaxilline, pyrapaxilline and shearinine B.

(Table 1), unisochronous methylene proton signals at $\delta 2.44$ and 2.59 ( $A B$ quartet), assigned to $27-\mathrm{H}_{2}$, were shown, instead of an olefinic $27-\mathrm{H}$ and an aliphatic $23-\mathrm{H}$ signals in those of $4 .{ }^{8}$ In comparison of the ${ }^{13} \mathrm{C}$ NMR data in $\mathrm{CDCl}_{3}$ and the optical rotation values of 1 and $\mathbf{3}$, it is suggested that $\mathbf{1}$ and the paxilline moiety of $\mathbf{3}$ have the same stereochemistry. The absolute structure of 1 was already determined by X-ray crystallographic analysis. ${ }^{7}$ The ${ }^{13} \mathrm{C}$ chemical shifts of 3 at $\mathrm{C}-2 \rightarrow \mathrm{C}-18$ were closely similar to those of 1 and 2 . Furthermore, 3 was levorotatery, $[\alpha]_{\mathrm{D}}^{21}-11^{\circ}(\mathrm{MeOH})$, as similar to those of $\mathbf{1},[\alpha]_{\mathrm{D}}^{25}$ $-6.0^{\circ}(\mathrm{MeOH})$. The stereostructure of 3 was elucidated as shown in Figure 1, and also confirmed in comparison with the NMR data of shearinine F. ${ }^{11}$

\section{Biological activities}

LPS increased NO production about 2.5 times over the basal level after $20 \mathrm{~h}$. When RAW264.7 cells were pretreated with 3 for $2 \mathrm{~h}$ prior to LPS stimulation, 3 inhibited LPS-induced NO production at $10-30 \mu \mathrm{g} \mathrm{ml}^{-1}$ without toxicity (Figure 3). Compound 3 inhibited $40 \%$ of NO production.

Paxilline (1) is known to inhibit high-conductance Ca-activated $\mathrm{K}$ channels, ${ }^{12}$ and it was reported to inhibit LPS-induced IкB- $\alpha / \mathrm{NF}-\kappa \mathrm{B}$ signaling in macrophages. ${ }^{13}$ In our assay system, $\mathbf{1}$ inhibited the NO production at $10 \mu \mathrm{g} \mathrm{ml}^{-1}$. Compound 2 was shown to inhibit NO production only weakly at $30 \mu \mathrm{g} \mathrm{ml}^{-1}$.

\section{DISCUSSION}

In the course of screening for the inhibitors of NO production, we have isolated paxilline and its two related compounds from the culture of fungus E. shearii. They are paxilline (1), 21-isopentenylpaxilline (2) and a novel compound 3. Novel analog (3) inhibited
LPS-induced NO production at $10-30 \mu \mathrm{g} \mathrm{ml}^{-1}$ without toxicity. Compound 3 possesses an additional dihydropyran ring, and was named as pyrapaxilline. The structure of $\mathbf{3}$ was appeared as shearinine $\mathrm{B}$ isomer in a patent application ${ }^{14}$ together with many paxillinerelated compounds. But, its data of characterization and structural determination of this compound have never been reported. Therefore, we have reported isolation and characterization of pyrapaxilline (3) as a novel compound in the present research.

\section{METHODS}

\section{General experimental procedures}

The EI-MS was measured with a JEOL GC Mate spectrometer (JEOL, Tokyo, Japan). HRESIMS was taken with a Waters LCT Premier XE spectrometer (Waters, Milford, MA, USA). NMR spectra were recorded on a JEOL JNMECA500 spectrometer (JEOL). The ${ }^{1} \mathrm{H}$ and ${ }^{13} \mathrm{C}$ chemical shifts were referenced to the solvent signal $\left(\delta_{\mathrm{H}} 7.26\right.$ and $\delta_{\mathrm{C}} 77.16$ in $\mathrm{CDCl}_{3}, \delta_{\mathrm{H}} 3.31, \delta_{\mathrm{C}} 49.0$ in $\mathrm{CD}_{3} \mathrm{OD}$ and $\left.\delta_{\mathrm{H}} 2.50, \delta_{\mathrm{C}} 39.5 \mathrm{in}\left(\mathrm{CD}_{3}\right)_{2} \mathrm{SO}\right)$. The UV spectra were recorded on a Hitachi U-3310 spectrophotometer (Hitachi, Tokyo, Japan). Optical rotations were measured on a JASCO P-2200 polarimeter (JASCO, Tokyo, Japan). IR spectra were recorded on a Bruker FT-IR ALPHA-T spectrometer (Bruker Optics K.K., Tokyo, Japan).

\section{Identification of producing strain and fermentation}

Fungal strain PF1443 (CR25679) was isolated from a soil sample collected at Okinawa, Japan. The phenotypic and genotypic data including base-sequence analyses of $28 \mathrm{~S}$ rDNA-D1/D2 and ITS-5.8S rDNA showed that this strain belongs to E. shearii. A slant culture of PF1443 (CR25679) was used to inoculate in 100-ml Erlenmeyer flasks. Each flask contained $20 \mathrm{ml}$ of a seed medium consisting of $2.0 \%$ soluble starch, $1.0 \%$ glucose, $0.5 \%$ polypeptone, $0.6 \%$ wheat germ, $0.3 \%$ yeast extract, $0.2 \%$ soybean meal and $0.2 \% \mathrm{CaCO}_{3}$ in deionized water adjusted to $\mathrm{pH} 7.0$ with $\mathrm{NaOH}$ aq solution prior to sterilization. The flasks were incubated at $25^{\circ} \mathrm{C}$ for 3 days on a rotary shaker 
Table $1{ }^{1} \mathrm{H}$ and ${ }^{13} \mathrm{C}$ NMR data of pyrapaxilline in $\mathrm{CD}_{3} \mathrm{OD}$

\begin{tabular}{|c|c|c|c|c|}
\hline Position & ${ }^{13} \mathrm{C}(\delta)$ & $D E P T$ & ${ }^{1} H(\delta$ mult $)(J, H z)$ & $H M B C$ \\
\hline 2 & 153.0 & C & & \\
\hline 3 & 52.0 & C & & \\
\hline 4 & 44.1 & C & & \\
\hline \multirow[t]{2}{*}{5} & 27.9 & $\mathrm{CH}_{2}$ & $1.67 \mathrm{~m}$ & C-13 \\
\hline & & & $2.68 \mathrm{~m}$ & $C-3,4$ \\
\hline \multirow[t]{2}{*}{6} & 29.1 & $\mathrm{CH}_{2}$ & $1.86 \mathrm{~m}$ & \\
\hline & & & $2.26 \mathrm{~m}$ & C-5 \\
\hline 7 & 74.5 & $\mathrm{CH}$ & $4.84 \mathrm{~m}$ & $\mathrm{C}-6,11,12$ \\
\hline 9 & 84.4 & $\mathrm{CH}$ & $3.72 \mathrm{~d}(0.2)$ & C-7, 34, 35, 36 \\
\hline 10 & 200.0 & $\mathrm{C}=\mathrm{O}$ & & \\
\hline 11 & 120.1 & $\mathrm{CH}$ & $5.73 d(1.7)$ & C-7, 9,13 \\
\hline 12 & 171.5 & $\mathrm{C}$ & & \\
\hline 13 & 77.6 & $\mathrm{C}$ & & \\
\hline 14 & 34.1 & $\mathrm{CH}_{2}$ & $1.46 \mathrm{brs}$ & C-16 \\
\hline \multirow[t]{2}{*}{15} & 22.2 & $\mathrm{CH}_{2}$ & $1.49 \mathrm{~m}$ & \\
\hline & & & $1.94 \mathrm{~m}$ & \\
\hline 16 & 50.7 & $\mathrm{CH}$ & $2.47 \mathrm{~m}$ & C-4 \\
\hline \multirow[t]{2}{*}{17} & 28.2 & $\mathrm{CH}_{2}$ & $2.33 \mathrm{dd}(14.5,10.5)$ & $\mathrm{C}-2,16,18$ \\
\hline & & & $2.67 \mathrm{~m}$ & $\mathrm{C}-2,15$ \\
\hline 18 & 117.0 & $\mathrm{C}$ & & \\
\hline 19 & 124.5 & C & & \\
\hline 20 & 114.1 & $\mathrm{CH}$ & $7.38 d(0.5)$ & $\mathrm{C}-18,19,22,31$ \\
\hline 21 & 139.8 & $\mathrm{C}$ & & \\
\hline 22 & 37.0 & $\mathrm{CH}_{2}$ & $3.34 \mathrm{brs}$ & C-28, 29 \\
\hline 23 & 142.7 & $\mathrm{C}$ & & \\
\hline 24 & 75.4 & $\mathrm{C}$ & & \\
\hline 26 & 73.2 & $\mathrm{C}$ & & \\
\hline \multirow[t]{2}{*}{27} & 35.3 & $\mathrm{CH}_{2}$ & 2.44 brd (15.8) & $\mathrm{C}-23,26,28,39,40$ \\
\hline & & & 2.59 brd (15.8) & C-23, $26,28,39,40$ \\
\hline 28 & 133.4 & C & & \\
\hline 29 & 135.3 & $\mathrm{C}$ & & \\
\hline 30 & 102.3 & $\mathrm{CH}$ & $7.13 d(0.5)$ & C-19, 29 \\
\hline 31 & 141.0 & $\mathrm{C}$ & & \\
\hline 32 & 16.6 & $\mathrm{CH}_{3}$ & $1.26 \mathrm{~s}$ & $\mathrm{C}-3,4,16$ \\
\hline 33 & 19.8 & $\mathrm{CH}_{3}$ & $0.77 \mathrm{~s}$ & $\mathrm{C}-3,4,5,13$ \\
\hline 34 & 73.3 & $\mathrm{C}$ & & \\
\hline 35 & 25.3 & $\mathrm{CH}_{3}$ & $1.29 \mathrm{~s}$ & \\
\hline 36 & 26.3 & $\mathrm{CH}_{3}$ & $1.27 \mathrm{~s}$ & \\
\hline 37 & 30.7 & $\mathrm{CH}_{3}$ & $1.43 \mathrm{~s}$ & C-23, 24 \\
\hline 38 & 30.8 & $\mathrm{CH}_{3}$ & $1.43 \mathrm{~s}$ & C-23, 24 \\
\hline 39 & 29.9 & $\mathrm{CH}_{3}$ & $1.33 \mathrm{brs}$ & C-26, 40 \\
\hline 40 & 30.0 & $\mathrm{CH}_{3}$ & $1.34 \mathrm{brs}$ & C-26, 39 \\
\hline
\end{tabular}

at 220 r.p.m. Portions of $1.0 \mathrm{ml}$ of this seed culture were transferred into two $500-\mathrm{ml}$ Erlenmeyer flasks, each of which contained $100 \mathrm{ml}$ of a seed medium. The flasks were incubated at $25^{\circ} \mathrm{C}$ for $48 \mathrm{~h}$ on a rotary shaker at 220 r.p.m. Portions of $150 \mathrm{ml}$ of the second seed culture were transferred into a stainless vat containing the solid culture medium consisting of $100 \mathrm{~g}$ of oatmeal and $4.0 \mathrm{~kg}$ of water-absorbed brown rice. The stainless vat was thoroughly stirred and then statically cultured at $25^{\circ} \mathrm{C}$ for 14 days.

\section{Extraction and isolation}

The obtained culture $(4.0 \mathrm{~kg})$ was extracted with 8.0 liters of $67 \%$ aq acetone. The extract (twice, 15.0 liters in total) was evaporated under reduced pressure to about a quarter of the original volume, and then extracted twice with 15.0 liters of EtOAc at $\mathrm{pH} 2.0$, and the extract was evaporated to give a brown residue $(21.9 \mathrm{~g})$. The residue was chromatographed on a silica gel column (Silica gel 60, $500 \mathrm{~g}, 0.063-0.200 \mathrm{~mm}$, Merck KGeA, Darmstadt, Germany, column size: $50 \times 500 \mathrm{~mm}$ ) and cut into 550 fractions (each $20 \mathrm{ml}$ ), using hexane-EtOAc (3:1). The major active fractions no. 350-500 were combined

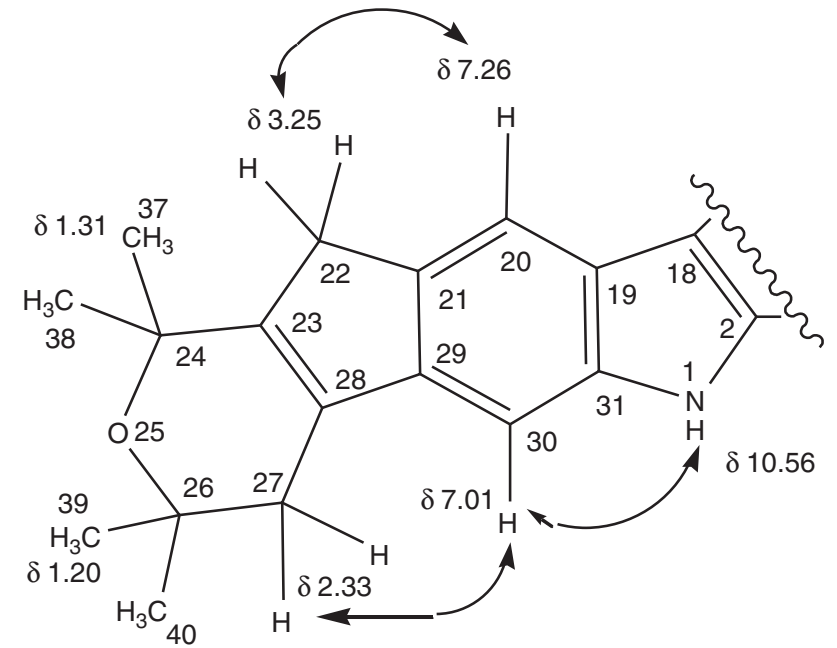

Figure 2 Key cross-peaks of pyrapaxilline in NOESY, $\left(\mathrm{CD}_{3}\right)_{2} \mathrm{SO}$.

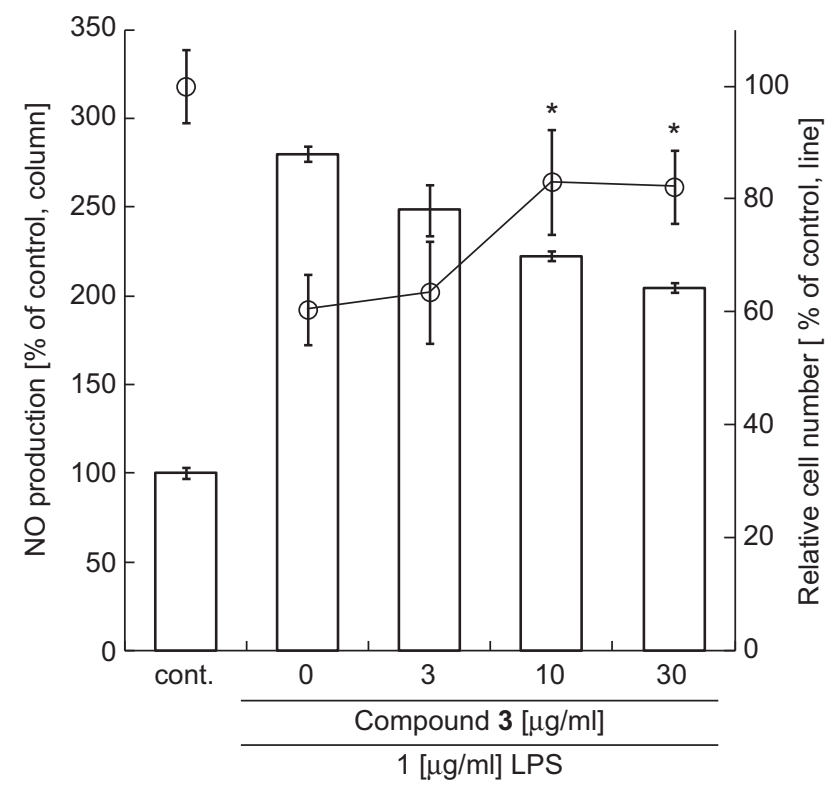

Figure 3 Inhibition of lipopolysaccharide (LPS)-induced nitrogen monoxide (NO) production by pyrapaxilline (3) in RAW264.7 cells. The LPS stiumulated-RAW264.7 cells were treated with 3 for $20 \mathrm{~h}$ then the NO production and cell number were assayed. Values are the means \pm s.d. of triplicate determinations. ${ }^{*} P<0.0005$ against column of $0 \mu \mathrm{g} \mathrm{ml}^{-1}$.

and concentrated to yellow residue $\left(832 \mathrm{mg}\right.$ ), showing an $R_{\mathrm{F}}$ of 0.67 on a silica gel TLC using hexane-EtOAc (3:1). The residue of $30 \mathrm{mg}$ was dissolved in $\mathrm{MeOH}$ and separated by HPLC (Pegasil ODS C18 column, $5 \mu \mathrm{m}$, Senshu Scientific, Tokyo, Japan; column size: $20 \times 250 \mathrm{~mm}, \mathrm{H}_{2} \mathrm{O} / \mathrm{CH}_{3} \mathrm{CN}$ : 30/70-5/95,

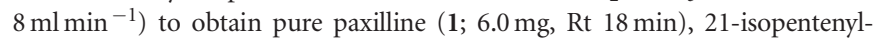
paxilline (2) (2.4 mg, Rt $28 \mathrm{~min}$ ) and pyrapaxilline (3) (2.4 mg, Rt $32 \mathrm{~min}$ ).

Paxilline (1). Colorless solid: $[\alpha]]_{\mathrm{D}}^{25}-6^{\circ}$ (c $\left.0.0867, \mathrm{MeOH}\right) ;{ }^{13} \mathrm{C}$ NMR $\left(125 \mathrm{MHz}, \mathrm{CDCl}_{3}\right) \delta 199.3,168.4,151.6,139.8,125.1,120.7,119.8,119.5$, $118.6,117.5,111.5,83.3,77.5,72.7,72.6,50.9,49.5,43.2,34.3,28.5,28.0$, 27.2, 26.6, 24.2, 20.9, 19.7 and 16.5; EI-MS $\mathrm{m} / \mathrm{z} 435\left(\mathrm{M}^{+}\right.$, calcd for $\left.\mathrm{C}_{27} \mathrm{H}_{33} \mathrm{NO}_{4}, 435\right)$.

21-Isopentenylpaxilline (2). Yellowish oil; ${ }^{13} \mathrm{C}$ NMR $\left(125 \mathrm{MHz}, \mathrm{CDCl}_{3}\right) \delta$ $199.6,168.5,152.1,138.6,133.7,131.8,125.6,124.9,121.8,120.0,118.0,117.5$, $111.7,83.6,77.9,72.9,72.8,51.1,49.8,43.5,34.9,34.7,28.8,28.3,27.5,26.9$, 26.2, 24.5, 21.2, 20.0, 18.2 and 16.6; EI-MS $\mathrm{m} / \mathrm{z} 503\left(\mathrm{M}^{+}\right.$, calcd for 
$\left.\mathrm{C}_{32} \mathrm{H}_{41} \mathrm{NO}_{4}, 503\right)$; HRESIMS $m / z 504.3094\left[(\mathrm{M}+\mathrm{H})^{+}\right.$, calcd for $\mathrm{C}_{32} \mathrm{H}_{42} \mathrm{NO}_{4}$, 504.3114].

Pyrapaxilline (3). Pale yellow solid: $[\alpha]_{D}^{25}-11^{\circ}$ (c $\left.0.2333, \mathrm{MeOH}\right)$; UV $\lambda \max ^{\mathrm{MeOH}}(\varepsilon) 243$ (11000), 283 (sh, 6600) and 316 (sh, 4100) nm; IR (KBr) $v_{\max } 3412,2973,2930,1665,1453,1376,1162$ and $1119 \mathrm{~cm}^{-1} ;{ }^{1} \mathrm{H}$ NMR $(500 \mathrm{MHz})$ and ${ }^{13} \mathrm{C}$ NMR data $(125 \mathrm{MHz})$ in $\mathrm{CD}_{3} \mathrm{OD}$ are shown in Table 1; NOESY experiment in $\left(\mathrm{CD}_{3}\right)_{2} \mathrm{SO}$ showed NOE correlations among $20-\mathrm{H}$ to $22-\mathrm{H}, 30-\mathrm{H}$ to $27-\mathrm{H}$ and $1-\mathrm{NH}$ to $30-\mathrm{H}$ (Figure 2$) ;{ }^{13} \mathrm{C} \mathrm{NMR}(125 \mathrm{MHz}$, $\left.\mathrm{CDCl}_{3}\right) \delta 199.4,168.4,151.0,143.2,139.8,139.8,133.5,131.8,120.3,119.7$, $117.3,113.8,101.1,83.3,77.4,72.8,72.6,72.6,71.2,51.0,49.3,43.3,36.8,34.5$, $34.5,30.4,30.4,29.8,29.7,28.6,28.1,26.7,26.7,24.3,21.0,19.8$ and 16.2 ; EI-MS $\mathrm{m} / z 585\left(\mathrm{M}^{+}\right.$, calcd for $\left.\mathrm{C}_{37} \mathrm{H}_{47} \mathrm{NO}_{5}, 585\right)$; HRESIMS $\mathrm{m} / \mathrm{z} 586.3553$ $\left[(\mathrm{M}+\mathrm{H})^{+}\right.$, calcd for $\left.\mathrm{C}_{37} \mathrm{H}_{48} \mathrm{NO}_{5}, 586.3532\right]$.

\section{Cell culture}

Mouse macrophage RAW264.7 cells were cultured in Dulbecco's modified Eagle's medium (Nissui, Tokyo, Japan) supplemented with $10 \%$ fetal bovine serum (JRH Biosciences, Lenexa, KS, USA), $200 \mu \mathrm{g} \mathrm{ml}^{-1}$ kanamycin (Sigma, St Louis, MO, USA), 100 units $\mathrm{ml}^{-1}$ penicillin G (Sigma), $600 \mu \mathrm{g} \mathrm{ml}^{-1}$ L-glutamine (Sigma) and $2.25 \mathrm{gl}^{-1} \mathrm{NaHCO}_{3}$ under a humidified atmosphere with $5 \% \mathrm{CO}_{2}$ and $95 \%$ air at $37^{\circ} \mathrm{C}$.

\section{NO production}

Cells $\left(1 \times 10^{5}\right.$ cells ml $\left.{ }^{-1}\right)$ were seeded in a 96-well plate (Corning, Corning, NY, USA) with each well receiving $100 \mu$ of the cell suspension..$^{15}$ On the next day, the cells were treated with chemicals for $2 \mathrm{~h}$ and then stimulated with $1 \mu \mathrm{g} \mathrm{ml}^{-1}$ LPS for $20 \mathrm{~h}$. Then, $100 \mu \mathrm{l}$ Griess reagent solution was added to each well. The concentration of $\mathrm{NO}$ was determined by measuring the absorbance at $570 \mathrm{~nm}$ with a microplate reader.

\section{MTT assay}

Cell suspension $\left(1 \times 10^{5}\right.$ cells ml $\left.^{-1}\right)$ of RAW264.7 cells at concentration of $50 \%$ confluence was seeded into the 96-well plate. Then, the cell suspensions were added into the plates and incubated for $20 \mathrm{~h}$. Next, $10 \mu \mathrm{l}$ of the MTT (3-[4,5-dimethylthiazol-2-yl]-2,5-diphenyltetrazolium bromide, Sigma) solution was added into each plate and incubated for $4 \mathrm{~h}$ at $37^{\circ} \mathrm{C}$ under $5 \% \mathrm{CO}_{2}$. Subsequently, the culture supernatant was replaced with $100 \mu \mathrm{l}$ dimethyl sulfoxide to dissolve formazan crystal made from succinic dehydrogenase in the mitochondria and its substrate MTT. An absorbance of $570 \mathrm{~nm}$ was measured with a microplate reader.

\section{CONFLICT OF INTEREST}

The authors declare no conflict of interest.

\section{ACKNOWLEDGEMENTS}

We thank Dr Shinichi Kondo, Bioscience Associates, Tokyo, for his valuable suggestions.

1 Korhonen, R., Lahti, A., Kankaanranta, H. \& Moilanen, E. Nitric oxide production and signaling in inflammation. Curr Drug Targets Inflamm Allergy 4, 471-479 (2005).

2 Ariga, A. Namekawa, J., Matsumoto, N., Inoue, J. \& Umezawa, K. Inhibition of tumor necrosis factor-alpha-induced nuclear translocation and activation of NF-kappa B by dehydroxymethylepoxyquinomicin. J. Biol. Chem. 277, 24625-24630 (2002).

3 Suzuki, Y., Sugiyama, C., Ohno, O. \& Umezawa, K. Preparation and biological activities of optically active dehydroxymethylepoxyquinomicin, a novel NF-KB inhibitor. Tetrahedron 60, 7061-7066 (2004).

4 Umezawa, K. Inhibition of tumor growth by NF-кB inhibitors. Cancer Sci. 97, 990-995 (2006).

5 Wang, Z., Igarashi, M., Ikeda, Y., Horie, R. \& Umezawa, K. Inhibition of NF-kappa B activation by 9 -methylstreptimidone isolated from Streptomyces. Heterocycles 69 , 377-383 (2006).

6 Tachibana, M., Matsui, C., Takeuchi, Y., Suzuki, E. \& Umezawa, K. Inhibition of NF-кB activation by penicillic acid and dihydropenicillic acid isolated from fungi. Heterocycles 76, 1561-1569 (2008).

7 Springer, J. P., Clardy, J., Wells, J. M., Cole, R. J. \& Kirksey, J. W. The structure of paxilline, a tremorgenic metabolite of Penicillium paxilli Bainier. Tetrahedron Lett. 16, 2531-2534 (1975).

8 Belofsky, G. N., Gloer, J. B., Wicklow, D. T. \& Dowd, P. F. Antiinsectan alkaloids: Shearinines $\mathrm{A}-\mathrm{C}$ and a new paxilline derivative from the ascostromata of Eupenicillium shearii. Tetrahedron 51, 3959-3968 (1995).

9 Singh, S. B. et al. Nodulisporic acids D-F: structure, biological activities, and biogenetic relationships. J. Nat. Prod. 67, 1496-1506 (2004).

10 Wilkins, A. L. et al. Structure elucidation of janthitrem B, a tremorgenic metabolite of Penicillium janthinellum, and relative configuration of the $A$ and $B$ rings of janthitrems B, E, and F. J. Agric. Food Chem. 40, 1307-1309 (1992).

$11 \mathrm{Xu}, \mathrm{M}$. et al. Shearinines D-K, new indole triterpenoids from an endophytic Penicillium sp. (strain HKI0459) with blocking activity on large-conductance calcium-activated potassium channels. Tetrahedron 63, 435-444 (2007).

12 Knaus, H. G. et al. Tremorgenic indole alkaloids potently inhibit smooth muscle high-conductance calcium-activated potassium channels. Biochemistry 33, 5819-5828 (1994).

13 Papavlassopoulos, M. et al. MaxiK blockade selectively inhibits the lipopolysaccharideinduced I kappa B-alpha/NF-kappa B signaling pathway in macrophages. J. Immunol. 177, 4086-4093 (2006).

14 Goetz, M. A. et al. (Merck \& Co. Inc.). Novel maxi-k channel blockers, methods of use and process for making the same. WO 03/105868, 24 December (2003).

15 Dubois, R. N. et al. Cyclooxygenase in biology and disease. FASEB J 12, 1063-1073 (1998) 